\title{
The Potential of German Administrative Models for the Resolution of Public-Private Partnership Barriers in Poland
}

\author{
Maria Schulders*
}

Public-private partnership (hereinafter: PPP) is not developing according to expectations in Poland. In comparison to other European nations, the success rate of initiated proceedings is still very low. Between 2009 and the first quarter of 2020, only 25\% of initiated proceedings were realized.

While there is a large number of potential factors influencing the poor outcome of PPP proceedings in Poland - including a small average project size as well as faults in the regulatory framework - this article addresses administrative barriers standing in the way of successful public-private partnership development. The use and necessity of independent advisors will be addressed, as well as the availability of governmental support mechanisms. Administrative solutions for PPP facilitation from Germany will be showcased, such as the PPP Task Force of the German Ministry of Transport, Building and Housing (BMVBW), as well as the creation of Partnerschaften Deutschland $A G(P D)$. The article then aims to showcase the applicability of German administrative models to the Polish PPP market on the basis of a comparative case study.

Keywords: public-private partnership, public administration, PPP barriers in Poland, public procurement.

Submitted: 08.02.2020 | Accepted: 15.06.2020

\section{Potencjał niemieckich modeli administracyjnych dla rozwiązywania barier partnerstwa publiczno-prywatnego w Polsce}

Partnerstwo publiczno-prywatne (dalej: PPP) nie rozwija się $w$ Polsce zgodnie z oczekiwaniami. W porównaniu z innymi państwami europejskimi wskaźnik powodzenia wszczętych postępowań jest nadal bardzo niski. Między 2009 r. a pierwszym kwartatem 2020 r. doszło do realizacji jedynie $25 \%$ wszczętych postępowań.

Chociaż istnieje wiele potencjalnych czynników wplywających na zły wynik postępowań PPP $w$ Polsce - w tym niewielka średnia wielkość projektu, a także wady w ramach regulacyjnych - w tym artykule omówiono bariery administracyjne stojące na drodze do udanego rozwoju partnerstwa publiczno-prywatnego. Uwzględnione zostanie wykorzystanie $i$ konieczność funkcjonowania niezależnych doradców, a także dostępność rządowych mechanizmów wsparcia.

\footnotetext{
Maria Schulders - MA, Faculty of Management, University of Warsaw, Poland, https://orcid.org/ 00000002-1416-9734.

Correspondence address: Faculty of Management, University of Warsaw, 1/3 Szturmowa Street, 02-678 Warsaw, Poland; e-mail: MSchulders@wz.uw.edu.pl.
} 
Zaprezentowane zostaly rozwiazania administracyjne dotyczace ułatwień PPP z Niemiec, takich jak grupa zadaniowa ds. PPP niemieckiego Ministerstwa Transportu, Budownictwa $i$ Mieszkalnictwa (BMVBW), a także utworzenie Partnerschaften Deutschland AG (PD). Artykut ma na celu zaprezentowanie możliwości zastosowania niemieckich modeli administracyjnych na polskim rynku PPP na podstawie porównawczego studium przypadku.

Słowa kluczowe: partnerstwo publiczno-prywatne, administracja publiczna, bariery PPP w Polsce, zamówienia publiczne.

Nadesłany: 08.02.2020 | Zaakceptowany do druku: 15.06.2020

JEL: E62, H50, H40

\section{Introduction}

Before 2030, an estimated PLN 1.5 trillion of capital investment is needed in order to maintain the current pace of infrastructure development in Poland (Ministry of Development Funds and Regional Policy [MFiPR], 2017).

The national budget in Poland does not permit the facilitation of said infrastructure investments - the lack thereof may however drastically hamper Poland's economic development (Ratajczak, 2000). This showcases the growing necessity for the implementation of private funds for the financing of social infrastructure in Poland. While the privatization of social services may offer a solution in some cases, it also poses risks which public entities should seek to avoid - such as limited access to social infrastructure for low-income individuals. Public-private partnership hence offers a convenient solution to said problem, as it facilitates the use of private funds while also retaining full accessibility and public control. PPP however is not developing in accordance to expectations in Poland: According to a 2020 report by the Ministry of Development Funds and Regional Policy (MFiPR), in the last decade, from the beginning of 2009 to March $31^{\text {st }} 2020$, a total of 574 PPP proceedings were initiated in Poland.

Figure 1. PPP proceedings and contracts concluded between 2009 and Q1 of 2020

\begin{tabular}{|c|c|c|c|c|c|c|c|c|c|c|c|c|c|}
\hline Phase & 2009 & 2010 & 2011 & 2012 & 2013 & 2014 & 2015 & 2016 & 2017 & 2018 & 2019 & \begin{tabular}{|c|}
$Q 1$ \\
2020
\end{tabular} & SUM \\
\hline $\begin{array}{l}\text { All initiated } \\
\text { proceedings }\end{array}$ & 38 & 60 & 43 & 80 & 70 & 52 & 61 & 60 & 36 & 47 & 22 & 5 & 574 \\
\hline Signed contracts & 2 & 12 & 13 & 20 & 23 & 18 & 25 & 10 & 11 & 16 & 9 & 3 & 162 \\
\hline \multicolumn{14}{|l|}{\begin{tabular}{|l|l|} 
& out of which:
\end{tabular}} \\
\hline $\begin{array}{l}\text { Contracts which } \\
\text { were realized: }\end{array}$ & 2 & 8 & 11 & 15 & 20 & 16 & 23 & 10 & 11 & 16 & 9 & 3 & 144 \\
\hline $\begin{array}{l}\text { Contracts } \\
\text { which were } \\
\text { not realized: }\end{array}$ & 0 & 4 & 2 & 5 & 3 & 2 & 2 & 0 & 0 & 0 & 0 & 0 & 18 \\
\hline
\end{tabular}

Source: Raport rynku PPP 2009 - I kw. 2020, Platforma PPP, Ministry of Development Funds and Regional Policy (2020).

Those proceedings led to the conclusion of 162 contracts, of which 144 entered the implementation phase. The development of procurement proceedings in Poland over the last decade is showcased in Figure 1 . Improvements in the project realization rate are observable in Poland. In
2010, 60 initiated proceedings resulted in 8 realized contracts $(13 \%)$, while in 2019 , 22 initiated proceedings concluded 9 realized contracts $(41 \%)$. The upward trend and development of the project realization rate is showcased in Figure 2. While said trend of project realization indicates an 
improvement in the use of PPP as a mode of social infrastructure financing, the data still points to a large problem: more than half of the initiated proceedings do not end with the conclusion of a contract. This is a very problematic and costly problem - both for the public as well as the private entities involved in the PPP procurement process. The preparation and drafting of a tendering offer is very cost- and time-consuming. Therefore, the fact that less than half of initiated proceedings succeed acts as a strong disincentive for private and public entities to engage in such a costly endeavor. It should hence be a prime objective of the Polish government to increase the project realization rate of initiated PPP proceedings.

Figure 2. Number of all proceedings and contracts initiated, including those which were not implemented, broken down by year

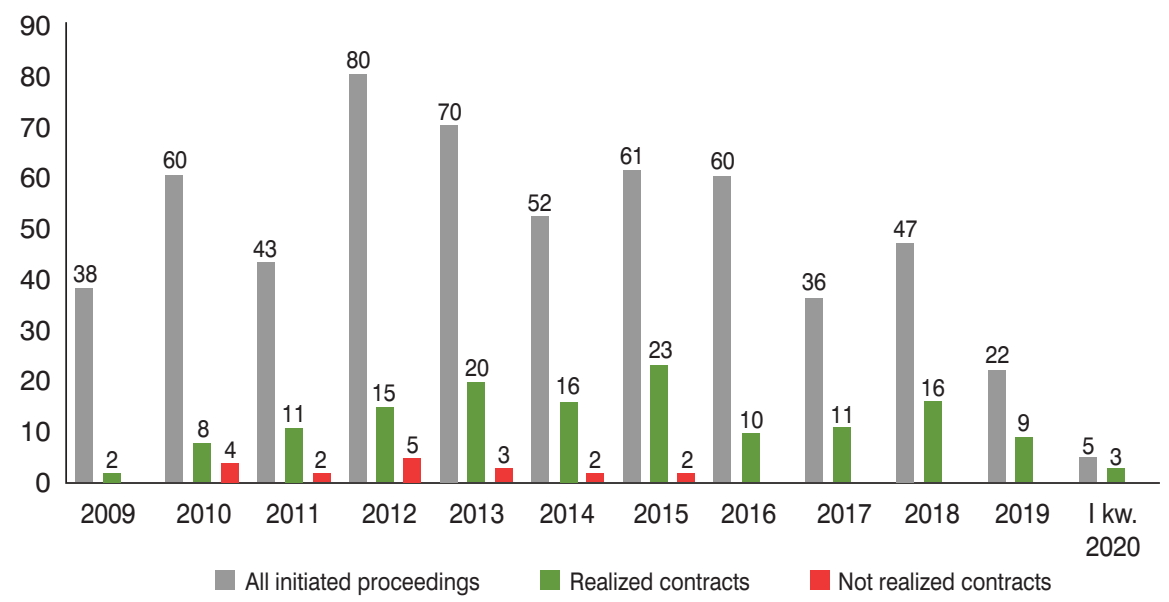

Source: Raport rynku PPP 2009 - I kw. 2020, Platforma PPP, Ministry of Development Funds and Regional Policy (2020).

There is a multitude of causes for the poor development of public-private partnership in Poland - the primary ones constituting financial (small average project size), legal (suboptimal regulatory frameworks) and institutional (the attitude of public authorities) barriers (Borowiec, 2017). With institutional frameworks and public authorities' attitudes being some of the main PPP development barriers in Poland, the domestic PPP market could significantly be aided by putting a stronger emphasis on administrative support mechanisms. This article thus addresses the current state of Polish PPP administrative models, as well as solutions from the German PPP market and their applicability to Poland, in selected cases.

\section{The Necessity of External Advisors}

Due to public-private partnership still being a relatively new mode of financing, many Polish municipalities have little to no experience with the PPP procurement process. A potential solution to said issue can be found in the use of external advisors, who could guide public entities through the PPP procurement process and thereby increase the percentage of initiated proceedings resulting in signed contracts. The use of external advisors is however still very rare in Poland: public entities used professional consultancy services in only approximately $46 \%$ of cases according to an analysis of 144 proceedings in the timeframe between 2009 and Q1 of 2020, as is showcased in Figure 3. 


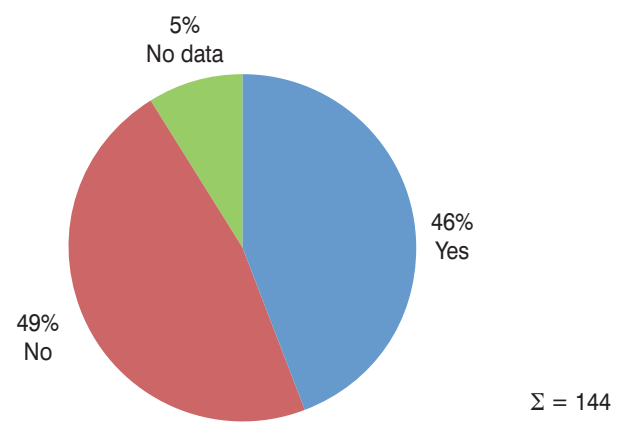

Source: Raport rynku PPP 2009 - I kw. 2020, Platforma PPP, Ministry of Development Funds and Regional Policy (2020).

Data from April 2016 (Korczyński, 2016) suggests that the use of external advisors may drastically increase the conclusion of an initiated proceeding in a signed contract, as is showcased in Figure 4, which visualizes the outcome of PPP procurement proceedings in the time from 2009 to April 2016 for all projects worth PLN 20 million or more.

Figure 4. Outcome of PPP procurement proceedings in the time from 2009 to April 2016 for all projects worth PLN 20 million or more

With advisors:

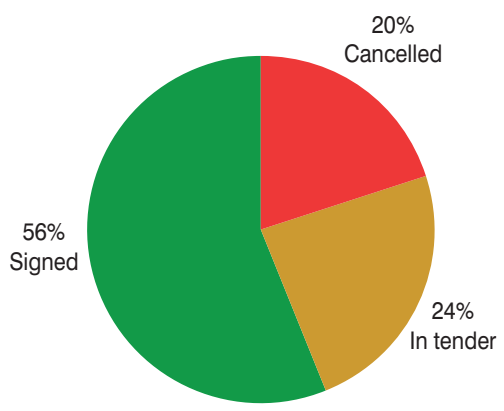

Without advisors:

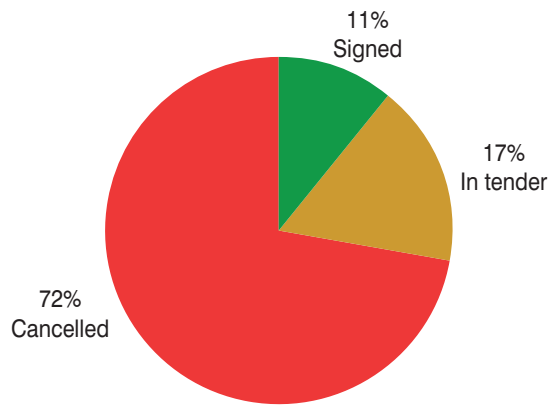

Source: Korczyński, T. (2016) - Perspektywy rynku PPP w Polsce, Green Warsaw Conferences.

One of the most crucial barriers for public entities seeking consultancy is the high cost associated with hiring legal support. The public entities which need PPP financing the most are frequently the ones which cannot afford legal support due to budgetary deficits. Centralized support mechanisms offered by the government are hence of high importance, as without them small municipalities with large deficits will not be accessing PPP for social infrastructure investments (Charytonowicz \& Falcão, 2018).

\section{Administrative Support Mechanisms}

In the first years of public-private partnership existence in Poland, governmental support mechanisms for PPP facilitation were next to non-existent. Recent years however showcased a very positive trend in this regard, with a number of PPP development projects being launched by the Ministry of Development Funds and Regional Policy (MFiPR).

The PPP facilitation actions outlined by the Ministry include, among others: 
- Governmental policy documents regarding the development of public-private partnership in Poland,

- A governmental database of planned and existing PPP projects,

- A PPP investment base with extensive information on concluded contracts,

- Proposals for changes in law that will facilitate the implementation of projects in the PPP formula,

- An extensive training project for central and local government administration,

- Central advisory support for PPP projects.

On July 26 ${ }^{\text {th }}$ 2017, the Council of Ministers adopted the Governmental Policy for the Development of PPPs (Ministry of Development Funds and Regional Policy [MFiPR]. Department for Public-Private Partnership Development, 2017a). The policy paper extensively outlines the reasoning for the urgent development of publicprivate partnership in Poland, as well as the planned steps towards its facilitation. According to the shortened version of the policy document (Ministry of Development Funds and Regional Policy [MFiPR], 2017b), "[a]n estimated PLN 1.5 trillion of capital investment is needed before 2030 in order to maintain the current pace of infrastructure development in Poland. Many key sectors of the economy have high investment needs. For example, the environment sector investment plan envisages the construction of $21,800 \mathrm{~km}$ of sewage networks, [...], and the modernization of 4,200 km of the existing sewage network, $[\ldots]$. In the railway sector, the reconstruction of 8,500 $\mathrm{km}$ of railway lines is planned. [...] [T]he construction of 0.5 million housing units is needed in order to address the existing deficit in the housing sector. Significant modernization of inland waterways is also envisaged, costing between PLN 24.6 billion and PLN 90.6 billion. In addition, more than PLN 200 billion is needed to implement the National Road Construction Program over the period 2014-2023".

According to the Ministry of Development Funds and Regional Policy (MFiPR), Poland's public budget (including the state budget) is not sufficient to facilitate the construction of said economic and social infrastructure investments. Not delivering on said infrastructure needs, on the other hand, can drastically hamper and reduce Poland's economic growth and potential
(Bennathan \& Canning, 2000). It is therefore essential to include sources of private financing in order to facilitate the necessary infrastructure investments and public services. Full privatization of social infrastructure is in many cases not possible due to legal constraints, as well as frequently not optimal from a social welfare perspective. Privatization could lead to access to certain, necessary social services to be made impossible to low-income individuals (Perry, 2015). PPP hence offers an efficient solution by implementing private funds with the government retaining full control over the accessibility of social infrastructure to its citizens.

After outlining the urgent need for PPP facilitation, the Ministry's policy paper then defines the planned undertakings in said pursuit. Improvement of the public administration's understanding of PPP is defined as a main focus of the governmental strategy, combined with ensuring coherence of the state administration's activities in the field of PPP.

A very positive example of said strategy outlined by the government can be found in an extensive training project that was launched in March 2017 - the goal of which is to facilitate PPP development in Poland. The "Development of publicprivate partnership in Poland" project is co-financed by the European Social Fund (Measure 2.18. High quality administrative services of the Operational Program Knowledge Education Development for 2014-2020). The main goal of the project is to improve the qualifications of public administration employees in the field of public-private partnership. Said project offers a package of free activities, such as trainings and workshops, as well as panel discussions and debates. It also includes the creation of guidelines for implementing PPP projects, as well as a free openaccess specialist PPP quarterly report. The leading role in the project is played by the Department of Public-Private Partnership in the Ministry of Development Funds and Regional Policy (Platforma PPP, MFiPR). The activities planned in the project fit into the objectives of the government's Strategy for Responsible Development (Ministry of Agriculture and Rural Development [MRiRW], 2016), by striving to increase the use of public sources of co-financing to stimulate private investment in social 
infrastructure. Governmental and administrative employees are invited to participate in a number of training programs with the goal of raising their qualifications and know-how. The Ministry hopes to increase the willingness of local governments to consider public-private partnership as a financing solution for social infrastructure. In said pursuit, it plans to train at least 1,400 public administration employees from over 600 institutions.

The project implementation period for the governmental training program is defined as taking place between January $6^{\text {th }} 2016$ and April 30 th 2021, with a project value of PLN 10,954,690.47. The majority of the project is co-financed by the European Social Fund (PLN 9,232,613.13).

The main focus of the abovementioned project is an extensive training program, which is specifically directed to:

- Local government units - including mayors; heads of municipalities; presidents; treasurers; employees responsible for investments, infrastructure and public procurement law.

- Government administration - including employees responsible for investments, infrastructure, legal and administrative issues; people working in connection with EU funds; units supervising the implementation of investments and their subordinate units.

- Central and control offices - including employees responsible for supervising the implementation of investments, as well as employees controlling the correctness and effectiveness of infrastructure projects.

The key characteristics of the governmental project are as follows:

- At least 1,400 training / workshop participants,

- Over 600 trained institutions,

- Over 100 workshop and training days,

- At least 5 supported PPP projects, with the goal of preparing comprehensive pre-implementation analyses,

- At least 15 publications, analyses and reports in the field of PPP,

- 10 examples of best practices from implemented PPP projects in Poland,

- 3 guidelines for implementing PPP projects,

- At least 30 economic events in the country and abroad, during which PPP promotional activities will be conducted.
The above-mentioned undertakings are a very positive development for publicprivate partnership facilitation in Poland.

Poland is however still very far away from a centralized administrative PPP support mechanism which can be found when analyzing the case of German public-private partnership policy.

\section{Administrative Solutions From Germany}

Public-private partnership is comprehensively structured by the German government, with PPP departments being present in different German ministries, as well as being part of administrative units on the local level (Müller, 2009). Said structured approach to public-private partnership development has been part of German politics since the early 2000s. In June 2002, the then German chancellor Gerhard Schröder announced the establishment of a federal PPP Task Force as part of the Ministry of Transport, Building and Housing (BMVBW) (Rosenkranz, 2014). Said task force played a major role in the early years of PPP development in Germany, coordinating and planning the nation-wide development of public-private partnership. The PPP Task Force supported both public as well as private entities in the PPP procurement process, offering guidelines and ready-to-use contract and tendering drafts. In addition, said task force formulated the first German governmental definition of what PPP constitutes in 2004. According to the task force's definition, a project can be referred to as a public-private partnership if it encompasses a contractually regulated, long-term cooperation between privateand public-sector entities in which a division of project gains and risks is outlined. The PPP Task Force described the primary gain of public-private partnership cooperation to be the exchange of resources and know-how, resulting in a financial gain for both of the parties involved. The existence of a central governmental entity offering extensive support and resources for German public administration is considered to be one of primary reasons for the success of the PPP formula in Germany (Gerstlberger \& Schneider, 2008). Small municipalities with little to no PPP experience could easily contact and consult experts and access support mechanisms - free of charge. After 
seven years of successfully offering administrative support to German public entities, the PPP Task Force of the Ministry of Transport, Building and Housing (BMVBW) was closed in 2009. The reason for said closure was the creation of a new support entity - the Partnerschaften Deutschland AG (PD). Said entity was also coined as a task force, however now being part of the German Ministry of Finance (BMF). The reason for the creation of Partnerschaften Deutschland AG was to offer even more comprehensive and nation-wide support to entities - both public and private - seeking public-private partnership. Its main objective is "to advise and support exclusively implementing public bodies and to adopt PPP structures to new sectors. Furthermore PD also supports the harmonization of PPP standards in the federal system and in different sectors, based on specific working committees that hold regular meetings together with the PPP competence centers on [the] federal [and] state level" (Just \& Maennig, 2012, p. 393). The implementation of the objectives of Partnerschaften Deutschland AG offers a very interesting case for analysis - the German government created PPP support entities on all levels of public administration, both centrally and locally. In addition, different areas of PPP implementation were divided by region and sector. This translated to PPP entities and task forces being established in different ministries, as well as experts being sent to local municipalities seeking public-private partnerships. Figure 5 showcases the structure of PPP entities in Germany.

Figure 5. The distribution of PPP divisions, working groups and task forces in Germany.

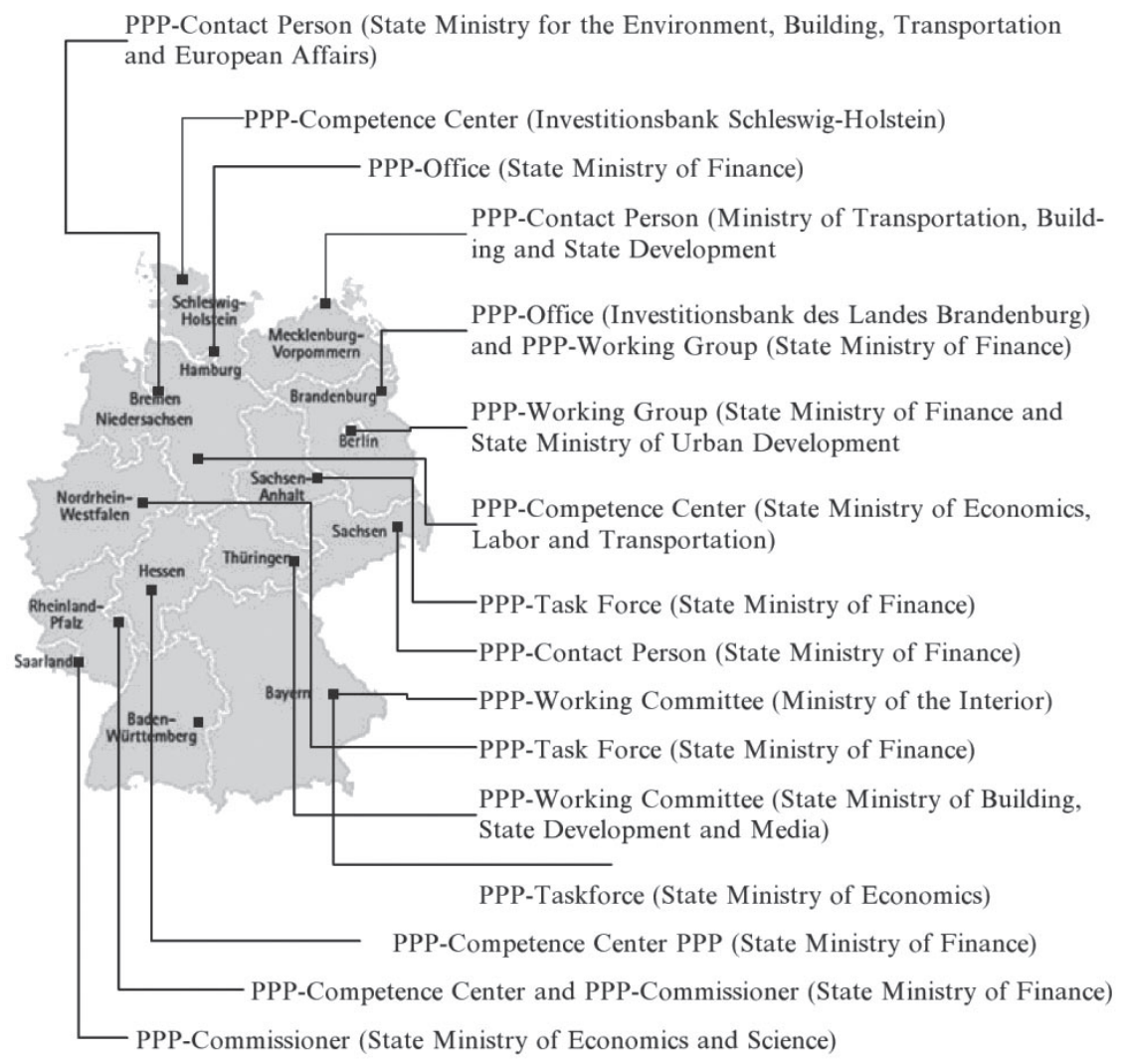

Source: Understanding German Real Estate Markets, Just, T. \& Maenning, W. (2012), p. 394.

The establishment of such a structure facilitated the standardization and harmo- nization of PPP guidelines on a federal level, as well as locally. It also allowed for 
an effective exchange of know-how and experiences, being particularly helpful for smaller inexperienced municipalities seeking the conclusion of a PPP.

\section{The Applicability of German Administrative Models to Poland}

The implementation of such a comprehensive solution is lacking Poland. Although there is the Department for Public-Private Partnership Development (Platforma PPP) being part of the Ministry of Development Funds and Regional Policy (MFiPR), it is by no means comparable in terms of size and complexity to the solutions which can be found in Germany - where most ministries and states have their own PPP department.

\subsection{Case Studies}

The differences regarding domestic PPP markets between Germany and Poland are most notable when comparing the project realization rate of initiated proceedings. While in Germany it is a rare occurrence for a tendered PPP not to conclude in a contract, in Poland less than half of initiated PPP proceedings are realized.

However, even among realized PPP projects, the lack of governmental support entities and advisors is observable in Poland. Delays caused by inaccurate risk assessment or a lacking public-sector comparator analysis are frequent, yet easily avoidable with improved schooling of administrative employees.

\subsubsection{Cemetery and crematory in Podgórki Tynieckie, Cracow}

One example of inaccurate risk assessment in the PPP process can be found when analyzing the case of the cemetery and crematorium project in Podgórki Tynieckie, Cracow. The tender was launched by the public entity in 2010 and included the construction and operation of a cremation infrastructure for human remains, a cemetery for both cremated and non-cremated remains and parking spaces adjacent to the cemetery. The city of Cracow provided the land for the infrastructure investment, while the private company was in charge of operating and maintaining the facility for 29 years and 7 months. The city negotiated an agreement based on concessions without additional payment: the private company which was awarded the contract - Italian Urciuoli Group S.R.L. - financed the construction of the cemetery and crematorium, while collecting income for the cremation and burial services it provided during the project run-time. Said model was chosen to ensure the profitability for the private party, while providing the city with muchneeded burial sites. After the end of the contract period, the infrastructure project would be handed to the city of Cracow for further maintenance and operation.

The investment was estimated to cost PLN 24.5 million of private party investment for the construction of the crematorium, administrative building, ceremonial building and cemetery. The city of Cracow agreed to build a road to the facility, along with pavement and street lighting, for an estimated PLN 2.1 million (Wolański et al., 2017).

It however quickly became evident that the public entity did not properly assess the project related risks: the crematorium project caused social outcry among local citizens with protests erupting by the planned construction site. The main cause for protest was likely religious objection to the cremation facility among the Catholic population, who used all possible means - including the proximity of the protected 'Natura 2000' area - to prove that the location of the crematorium would worsen the living conditions and endanger the environment. Said problem led to the investment being postponed by several years, while also putting the construction of the project in jeopardy as the City of Cracow issued a commercial guarantee to the investor. With construction permits being delayed by 3.5 years, the facility finally opened for operation in 2016. The delay and local disputes led to financial losses for the city of Cracow, while also posing a potential disincentive for private entities for the conclusion of future public-private partnerships. A rigorous risk-matrix assessment, which is frequently lacking in Polish PPP projects, would have likely prevented said situation, or at lease given the city of Cracow time to prepare the local population for the planned construction of the controversial investment project. Neither did the public entity conduct a publicsector comparator analysis prior to awarding the contract to Urciuoli Group S.R.L., hence failing to prove for the PPP model 
to be more cost-effective in said case as compared to project self-realization. The financing of the project was conducted via project finance - the most common financing method in Polish PPP projects.

\subsubsection{The Gladbeck city hall project}

The city hall project in Gladbeck, Germany, consisted of the demolition of the previous city hall building combined with the construction of a new, updated facility.

Prior to launching the tender offer in 2003, the city of Gladbeck tasked a team of technical, financial and legal advisors with calculating the cost of construction and maintenance. The economic analysis they performed, also called the public-sector comparator, showcased savings of approximately $13.5 \%$ if a PPP solution were to be chosen (Finanzverwaltung des Landes NordrheinWestfalen, 2006). After receiving said PSC confirmation, the public entity initiated the tendering process resulting in the signing of a contract between the city of Gladbeck and the private investor Hochtief in 2004. The project run-time amounted to 25 years, with the private partner being responsible for planning and construction, operation and maintenance. The total project value is EUR 44 million (the investment alone being EUR 16.5 million, leaving EUR 27.5 million for Hochtief's remaining expenses like maintenance or renovations). Said amount was to be paid by the public entity with monthly availability payments. At the end of the project runtime, the infrastructure was to be taken over by the public entity.

The project was financed by forfaiting, the most commonly used financing option in Germany: after the city hall was constructed, the company sold the right to collect availability fees to the bank from which it had taken the loan, translating to the bank possessing the right to collect said fee directly from the public entity itself. Said model puts more financial risk onto the public entity, thereby reducing the cost of the loan.

The Gladbeck city hall building was delivered on time and within budget, and is considered to be one of the most successful PPP projects in Germany - having been awarded a 2008 European architecture prize as the best publicly funded reconstruction measure (Lokalkompass Gladbeck, 2016).

\subsection{Summary}

The two case studies outlined above showcase the differences of PPP practice between Germany and Poland, such as:

- Public-sector comparator analysis being common practice in Germany, yet frequently lacking in Poland.

- Project finance being usually chosen by Polish public entities conducting PPPs, while in Germany the cheaper forfaiting by waiver model is more common.

- Polish public entities frequently have flawed or lacking project risk assessment, which constitutes a less notable problem in Germany.

It is important to note that German municipalities are more experienced in PPP, while also having a significantly stronger governmental support mechanism offering guidance during the complex procurement process. It comes hence as no surprise that German PPP projects are, on average, more successful.

\section{Conclusions}

There is a vast difference between the PPP markets of Germany and Poland. While some may be traced to size differences of the two economies, part of it is certainly caused by administrative practice, support and know-how.

Applying a similar model to that of Germany to Poland could drastically increase the project realization rate of initiated PPP proceedings, thereby also increasing the willingness of private sector entities to participate in PPP procurement processes. This in turn could lead to an increase in competition during the PPP process, thereby lowering the cost of the final project for the public entity.

The PPP procurement process constitutes a complex mechanism, requiring a proper risk assessment and legal support. Polish municipalities could significantly benefit from a centralized PPP support mechanism, like that present in Germany. As mentioned previously, less than half of public entities use consultancy services during the PPP procurement process in Poland. A main reason for such a low rate of the use of external advisors is likely the high cost associated with hiring a team of lawyers - small public entities simply do not have the finances for doing so, while also frequently being the ones most in need 
for social infrastructure investments via public-private partnership. The correlation between the use of external advisors and PPP project success is showcased in Figure 4 - and a causal relationship appears likely, taking into account the inexperience of many Polish public entities in the field of PPP.

While the Polish government recognizes the need for comprehensive support in the pursuit of PPPs - as can be seen in the example of the "Development of public-private partnership in Poland" project, there has yet to be the creation of nation-wide task forces offering knowledge and legal support to inexperienced public administration officials pursuing the conclusion of public-private partnerships. The creation thereof, while constituting significant additional expenses for the Polish government, could ease the use of private finances for social infrastructure investments, thereby increasing the rate of economic development in Poland.

Applying German administrative solutions could hence also benefit Poland from a social welfare perspective. The link between inequality (as measured by the Gini coefficient) and undesirable social developments (such as crime and violence) is well established (Farris, 2010). Currently, large inequalities are observable in Poland (Murawska, 2017) - particularly between the rural and urban populations. Municipalities in Poland's rural areas are in many cases urgently needing social infrastructure renovation, such as the modernization of schools and hospitals. Providing said modernization via PPP could hence increase equality between Poland's rural and urban populations - leading to overall desirable welfare outcomes nationwide.

\section{References}

Borowiec, A. (2017). Partnerstwo publiczno-prywatne: zagrożenia i bariery stosowania w polskich przedsiębiorstwach w świetle badań empirycznych. Zeszyty Naukowe Politechniki Poznańskiej Organizacja $i$ Zarzadzanie. https://doi.org/10.2100 8/j.0239-9415.2017.075.05.

Canning, D., \& Bennathan, E. (2000). The social rate of return on infrastructure investments (World Bank Policy Research Working Paper). https://doi. org/10.1596/1813-9450-2390.
Charytonowicz, J., \& Falcão, C. (2018). Advances in human factors, sustainable urban planning and infrastructure. Springer International Publishing. https:// doi.org/10.1007/978-3-319-94199-8

Farris, F. A. (2010). The Gini index and measures of inequality. American Mathematical Monthly. https:// doi.org/10.4169/000298910X523344.

Finanzverwaltung des Landes NordrheinWestfalen, Rathaus in Gladbeck. (2006). Retrieved from: https://www.finanzverwaltung.nrw.de/.

Gerstlberger, W., \& Schneider, K. (2008). Öffentlich Private Partnerschaften: Zwischenbilanz, empirische Befunde und Ausblick. Band 31 von Modernisierung des öffentlichen Sektors. Edition Sigma, 7-9.

Just, T., \& Maennig, W. (2012). Understanding German real estate markets. In Understanding German real estate markets (pp. 391-395). https://doi. org/10.1007/978-3-642-23611-2.

Korczyński, T. (2016). Perspektywy rynku PPP w Polsce. Presentation at Green Warsaw Conferences.

Lokalkompass Gladbeck. (2016). 10 Jahre "Neues Rathaus Gladbeck": Ein Erfolgskonzept feiert sich. Retreived from: https://www.lokalkompass.de/.

Ministry of Agriculture and Rural Development (MRiRW). (2016). Strategia zrównoważonego rozwoju polski do roku do roku 2025.

Ministry of Development Funds and Regional Policy (MFiPR). Department for Public-Private Partnership Development. (2017a). Uchwata Nr 116 / 2017 Rady Ministrów z dnia 26 lipca 2017 roku w sprawie przyjęcia dokumentu „Polityka Rzadu $w$ zakresie rozwoju partnerstwa publiczno-prywatnego".

Ministry of Development Funds and Regional Policy (MFiPR). (2017b). Polityka rzadu w zakresie rozwoju partnerstwa publiczno-prywatnego. Zatacznik do uchwaty nr 116/2017 Rady Ministrów z dnia 26 lipca 2017 r. (RM-111-83-17).

Ministry of Development Funds and Regional Policy (MFiPR). Department for Public-Private Partnership Development. (2020). Raport rynku PPP 2009 - I kw. 2020.

Müller, B. (2009). The development of a national PPP unit: The German experience. Regional Conference on Concessions and Public-Private Partnerships, Zagreb, 3-4 December 2009.

Murawska, A. (2017). Ocena nierówności społecznych na obszarach wiejskich w Polsce w świetle realizacji celów polityki spójności. Naukowe Stowarzyszenia Ekonomistów Rolnictwa i Agrobiznesu, XIW(III). https://doi.org/10.5604/01.3001.0010.3250.

Perry, D. C. (2015). Infrastructure investment. In International encyclopedia of the social \& behavioral sciences (2nd ed.). https://doi.org/10.1016/B978-008-097086-8.71012-9. 
Ratajczak, M. (2000). Infrastruktura a wzrost i rozwój gospodarczy. Ruch Prawniczy, Ekonomiczny i Socjologiczny, LXII(4).

Rosenkranz, M. (2014). Beschreibung der Entwicklung des Public Private Partnership am Beispiel des Bundeslandes NRW. diplom.de, 19-22.
Wolański, M., Mrozowski, W., \& Zaremba, M. (2017) Public-private partnership - Theory, best practices and the newest Polish experience. SGH Warsaw School of Economics Publishing House. 